\title{
Cactus as Crop Plant - Physiological Features, Uses and Cultivation -
}

\author{
Takanori HoRIBE \\ College of Bioscience and Biotechnology, Chubu University, Kasugai, Aichi 487-8501, Japan
}

(Received March 7, 2020; Accepted July 1, 2020)

\begin{abstract}
Today, the stems of edible Opuntia are consumed as vegetables, cattle food, and processed food, in addition to being used for raw materials in cosmetics and medical supplies in various countries, including the Mediterranean, South America, the Middle East, North Africa and Asia, showing their wide adaptability to various climate zones ranging from arid, semiarid to temperate zones. In a time when global warming and population growth requires an urgent response, there is intense demands in crops like edible Opuntia, which are stress-resistant to extreme environments (e.g., high temperature, dryness) and can be grown in large volumes. Thus, Edible Opuntia have promising potential not only to become general crop consumed globally but also to serve as a model plant for deciphering the mechanisms of their special properties. However, their existence and their traits as crop are not well-known at the global level compared with other global crops. This review explains the physiological features, uses and cultivation technologies including soil and hydroponic culture of edible Opuntia with recent researches.
\end{abstract}

Keywords : dryland agriculture, environmental control, hydroponics, Opuntia, production

\section{INTRODUCTION}

Family Cactaceae comprises an exciting group of plants because of their varied morphology, succulence, and adaptations to the environment. This family includes more than 1,500 species belonging to ca. 127 genera (Barthlott and Hunt, 1993; Hunt et al., 2006). Cacti occur naturally from just south of the Arctic Circle in Canada to the tip of Patagonia in South America (Rebman and Pinkava, 2001), with the greatest concentration of species richness being primarily in Mexico. Cacti show great adaptation to various environments. They grow at altitudes ranging from below sea level to more than 4,500 $\mathrm{m}$ in the Andes and in a broad range of climates (Rebman and Pinkava, 2001), from areas that have little rainfall to areas with more than 500 $\mathrm{cm}$ annual precipitation. The sizes of cacti range from 3 $\mathrm{cm}$ high to $20+\mathrm{m}$ high, and the larger ones can weigh several tons (Rebman and Pinkava, 2001).

Pereskioideae, Opuntioideae, and Cactoideae have been recognized as distinct subfamilies within family $\mathrm{Cac}$ taceae from taxonomic studies since the 19th century (Anderson, 2001; Metzing and Kiesling, 2008). The genus Maihuenia has been typically considered as a member of the Pereskioideae. However, the placement of Maihuenia in a monogeneric subfamily has been suggested on the basis of its unique ecological and morphological attributes (Anderson, 2001) and of molecular phylogenetic analyses (Wallace, 1995a; b). Nyffeler (2002) has suggested that the species of Pereskia and Maihuenia form an early-diverging grade within family Cactaceae, with Cactoideae and Opuntioideae as well-supported clades. Members of the subfamily Pereskioideae are large trees or shrubs with thin, broad, ordinary-looking leaves and hard, woody, nonsucculent trunks; they are not adapted to dry and hot conditions (Mauseth, 2006). The subfamilies Maihuenioideae and Opuntioideae contain plants with small but still easily visible foliage leaves and that vary from being high to dwarfs (Mauseth, 2006). The largest subfamily, Cactoide$a e$, is characterized by either tubercles or ribs on the stems, with either reduced or suppressed leaves subtending each areole (Wallace and Gibson, 2002). The subfamily Opuntioideae is most easily defined by its structural synapomorphies: (1) the areoles have glochid (small, barbed, and deciduous spines that are dislodged easily); (2) every cell constituting the outer cortical layer of the stem possesses a large druse (an aggregate crystal of calcium oxalate); (3) pollen grains are polyporate and possess peculiar microscopic exine features; (4) the seed is surrounded by a funicular envelope, often described as being an aril; and (5) special tracheids occurring in secondary xylem possess only annular secondary thickenings (Bailey, 1964; Gibson, 1978; Gibson and Nobel, 1986; Mauseth, 1995; Wallace and Gibson, 2002)

The flat-stemmed prickly-pear cactus is a crop with a high capacity to adapt to different environmental conditions, including arid (less than $250 \mathrm{~mm}$ annual precipitation) and semi-arid (250-450 $\mathrm{mm}$ annual precipitation) climates as well as the temperate zone (Reynolds and Arias, 2001) (Fig. 1). It belongs to the genus Opuntia (subfamily Opuntioideae, family Cactaceae), represented by more than 100 species that are native to Mexico (Bravo, 1978). The species of Opuntia are a major source of fruit, vegetable, and forage in areas where the soils are either poor or

Corresponding author : Takanori Horibe, fax: +81-92-642-2923, e-mail : t-horibe@isc.chubu.ac.jp 


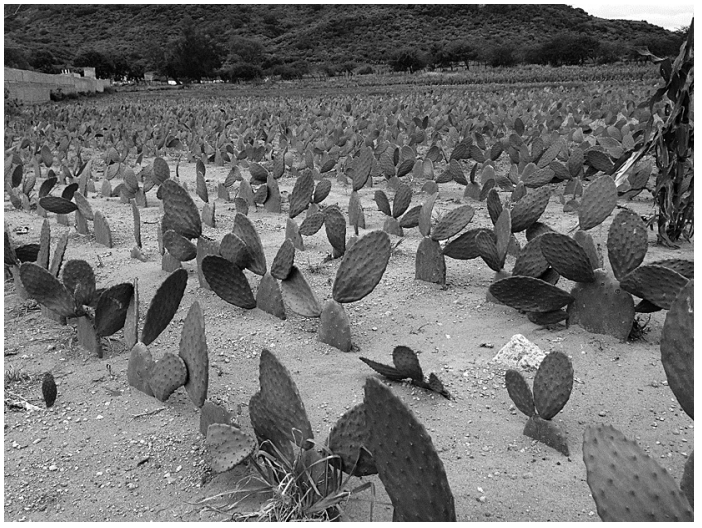

Fig. 1 Opuntia field in Guadalajara, Mexico. Cladodes approximately one year after planting. Young tender cladodes are harvested and consumed as vegetables, forage, and other processed items.

are becoming poor and produce a very low yield of traditional cultivars (García-Saucedo et al., 2005). Some of these Opuntia species have been used by human beings for hundreds of years in various ways: for animal feed; in the production of natural dyes, such as cochineal red; as vegetables for human consumption; and as a source of nutraceutical compounds (Guzmán-Maldonado and Paredes-López, 1999; Silos-Espino et al., 2006). For example, the stems of Opuntia are widely consumed as a vegetable in Mexico, Latin America, South Africa, and Mediterranean countries (Stintzing and Carle, 2005; Cruz-Hernández and ParedesLópez, 2010; El-Mostafa et al., 2014). This particular cactus is a valuable resource, particularly during drought when there is a shortage of other herbaceous plants for vegetables and forage (Le Houerou, 2000; Juárez and Passera, 2002; Shedbalkar et al., 2010).

In this review, we describe the physiological and morphological features, uses and cultivation technologies of Opuntia plants with recent progress. We also suggest that hydroponics and environmental control using plant factories can be effective tool in enhancing the productivity and functionality of edible Opuntia at last section.

\section{PHYSIOLOGICAL AND MORPHOLOGICAL FEATURES OF CACTI}

\section{Succulent stem tissue and photosynthesis}

Cacti have evolved to grow in environments where water is scarce, and they have characteristic physiological and morphological features (Fig. 2). Stems of most cacti are swollen with water storage tissue and can store considerable amounts of water, which enables them to survive in harsh environmental conditions (Lüttge, 2004). The stems function as the main photosynthetic system in most species of cacti. Thus, most cacti do not produce any leaves and are adapted to withstand water loss and drought conditions (Mauseth, 2006). However, Opuntia plants have rudimentary leaves in their juvenile stages. Most cactus species possess thin-walled epidermal cells although the external walls of species of Armatocereus, Cereus, Jasminocereus, and Mammillaria are thicker than their internal and radial walls (Mauseth, 1996).
(A)

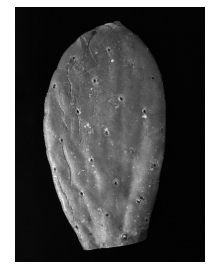

(B)

(C)

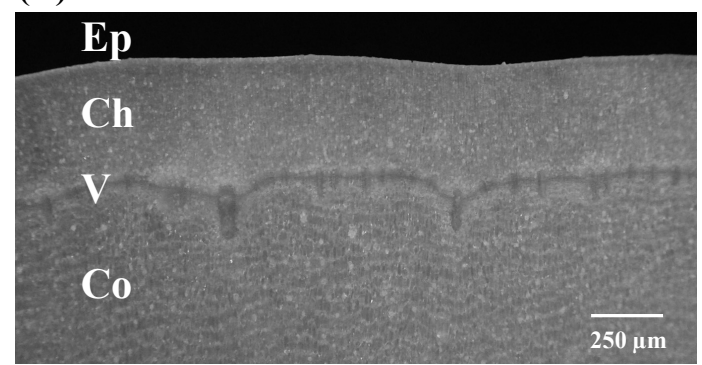

Fig. 2 Morphology of O. ficus-indica cladodes. (A) Whole cladode. (B) Transverse section of part of the whole cladode. (C) Transverse section of the outer layers of the cladode. Epidermis (Ep), chlorenchyma (Ch), vascular $(\mathrm{V})$, and core $(\mathrm{Co})$ tissue.

The external epidermal cell wall may be either flat or convex. In several species of Opuntia, convex projections are recognized (Salgado and Mauseth, 2002). Convex projections in the form of papillae, either as a single epidermal cell or as a series of cells, can affect transpiration by influencing the boundary layer of air adjacent to a stem surface (Fahn, 1986; Salgado and Mauseth, 2002). In addition, cacti stems have a waterproof epidermis covered with a thick waxy cuticle, and many have ribs so that the stem can expand and contract without damage to the surface tissues in the process of storing and utilizing water (Shedbalkar et al., 2010). Cuticle thickness varies from $1 \mu \mathrm{m}$ to $>200 \mu \mathrm{m}$ in the species of Cactoideae and from 8 to $58 \mu \mathrm{m}$ for the species of Opuntia (Pimienta-Barrios et al., 1993). Variations in cuticular thickness may be related to the water-conserving ability of a species. A thick cuticle may also increase the reflection of radiation, reducing stem temperature (Nobel, 1999). The epidermis contains crystals of different shapes and sizes, with oxalates being the most common, which may be the result of both over-accumulation of soil calcium levels and water lost through evaporation. Calcium oxalate crystals are physiologically and osmotically inactive; however, they can act as a protective barrier against insects, making it more difficult for insects to chew through the epidermis (Ventura-Aguilar et al., 2017).

A hypodermis generally occurs under the epidermis and usually consists of more than one cell layer in the stem succulents of Cactoideae and Opuntioideae (Mauseth and Landrum, 1997; Mauseth, 1999). Both the number of hypodermis layers and cell wall thickness may be related to the rigidity and xeromorphy of the stems. The cell walls of the hypodermis are often thickened with an accumulation of pectin substances (Gibson and Nobel, 1986). For Opuntia plants, the hypodermis consists of a single layer of cells, 


\section{CACTUS AS CROP PLANT}

many of which contain solitary druses and a multilayered band of strong collenchymatous cells (Conde, 1975; Pimienta-Barrios et al., 1993; Salgado and Mauseth, 2002). Because of its thickness and presence of druses, the hypodermis can affect the penetration of solar radiation into the underlying chlorenchyma (Pimienta-Barrios et al., 1993). Stomatal frequencies for cacti are $20-80$ per $\mathrm{mm}^{2}$, which are lower than those for leaves of $\mathrm{C}_{3}$ and $\mathrm{C}_{4}$ species, where 100-300 per $\mathrm{mm}^{2}$ is common (Nobel, 1999; Nobel and De la Barrera, 2000; Salgado and Mauseth, 2002).

In addition, the stomatal pore openings of cacti tend to be large compared with those of other dicotyledons. For example, the major pore axis varies from 33 to $62 \mu \mathrm{m}$ in several species of Opuntia, whereas it tends to be approximately $20 \mu \mathrm{m}$ for non-cacti (Pimienta-Barrios et al., 1993; Nobel, 1999). The area of open stomatal pores for cacti tends to be lesser than that for the leaves of $\mathrm{C}_{3}$ and $\mathrm{C}_{4}$ species, reflecting the water-conserving use of crassulacean acid metabolism (CAM) by cacti (Salgado and Mauseth, 2002). Opuntia plants also exhibit CAM, a $\mathrm{CO}_{2}$-concentrating mechanism that potentially leads to high optimal temperatures for photosynthesis (Monson, 1989).

Opuntia leaves tend to be ephemeral and do not contribute substantially to the net $\mathrm{CO}_{2}$ uptake of the entire shoot (Nobel and Bobich, 2002). Thus, $\mathrm{CO}_{2}$ uptake occurs primarily via the stem. CAM plants can survive droughts owing to certain anatomical modifications, i.e., thick cuticles and low stomatal frequency, along with night-time $\mathrm{CO}_{2}$ uptake (Drennan and Nobel, 2000; Pimienta-Barrios et al., 2005). Opuntia plants show considerable plasticity, varying in response to environmental conditions and according to developmental state (Cushman and Bohnert, 1999; Drennan and Nobel, 2000). Under wet conditions and moderate temperatures, some net $\mathrm{CO}_{2}$ uptake tends to occur in the early morning, using 1,5-ribulosebisphosphate carboxylase/oxygenase (Rubisco) via the $\mathrm{C}_{3}$ pathway (Nobel and Bobich, 2002). In addition, young daughter cladodes show $\mathrm{C}_{3}$ photosynthesis with daytime stomatal opening during the early stages of development (Osmond, 1978; Acevedo et al., 1983) and import water from mother cladodes (Pimienta-Barrios et al., 2005). Opuntia plants are characterized by high water use efficiency of 4-10 mmol $\mathrm{CO}_{2}$ per mol $\mathrm{H}_{2} \mathrm{O}$, compared with $\mathrm{C}_{3}$ and $\mathrm{C}_{4}$ plants, with $1.0^{-1.5} \mathrm{mmol}$ and 2-3 mmol $\mathrm{CO}_{2}$ per mol $\mathrm{H}_{2} \mathrm{O}$, respectively (Stintzing and Carle, 2005). These photosynthetic features increase, by a tremendous amount, not only the efficiency of water use in Opuntia plants but also the plants' ability to thrive in semi-arid environments either characterized by a restricted water supply or where long periods of drought and relatively high temperatures occur.

Areole

The areole is the most distinctive morphological trait in cacti and is recognized as a Cactaceae synapomorphy. In Cactaceae, the areole is the organ that forms the leaves, spines and buds. The stem of Edible Opuntia or photosynthetic body is represented by a long shoot (Mauseth, 2006) that bears a large number of areoles. With respect to growth behavior, daughter cladodes develop from the areole of the mother cladode, and this process is repeated
(Pimienta-Barrios et al., 2005). The areole has been traditionally recognized as a structure homologous to the axillary bud (Gibson and Nobel, 1986). However, it is regarded as a short shoot covered with trichomes and that dynamically produces stems (long shoots), leaves, spines, and/or flowers (Mauseth, 2006). The enclosed areole meristem and internal bud development are understood to be an adaptation to protect the meristem and bud from low temperatures (Sánchez et al., 2015).

Recent taxonomic synthesis of the Cactaceae family revealed the diversity and dynamics of the areole meristem in Cactaceae (Hunt et al., 2006). Of the 1438 species in the Cactaceae family, about $85 \%$ have monomorphic areoles; trichomes, stems or branches, leaves, spines and/or flowers are produced on the areole surface (Hunt et al., 2006; Sánchez et al., 2015). The remaining $15 \%$ of the species, included in the subfamily Cactoideae, show certain modifications in the morphology and anatomy of their areoles, which are expressed in the placement of their organs (Sánchez et al., 2015). For instance, Mammillaria has dimorphic areoles in which a spiny areole appears on the apex of the tubercle and a flower-bearing areole appears in the axil (Boke, 1953;1955;1958; Sánchez et al., 2015). On the other hand, Coryphantha, Escobaria and Neolloydia have pseudo-dimorphic areoles that are elongated over the tubercle and produce spines on the proximal region and flowers or stems on the distal end (Boke, 1952;1961; Sánchez et al., 2015).

Spines

Most cacti, including Opuntia, have spines on the surface of their stems. Cactus spines are thought to be either the modified bud scales of an axillary bud or the modified leaves of a short shoot (Mauseth, 1976; Boke, 1980). The differences between the two theories are not obvious. The Opuntioideae differ from all other subfamilies in having both glochids and spines on their stems (Rebman and Pinkava, 2001). Glochids are present along the adaxial margin of the areoles and easy to come off, sometimes leaving hundreds of them on one's hand who touched Opuntia stem. They are composed of $100 \%$ crystalline cellulose (Pritchard and Hall, 1976). Although most cacti spines, there are several variations in their color and shape among them. These include erect to spreading, whitish, tan or brown, setaceous only, or setaceous and subulate, straight to slightly curved, basally angular-flattened, or appear as small bristle-like deflexed spines to $5 \mathrm{~mm}$ (Shedbalkar et al., 2010). Spines are composed of $96 \%$ polysaccharides consisting of $49.7 \%$ cellulose and $50.3 \%$ arabinan (Malainine et al., 2003). The cellulose microfibrils, 0.4 $\mathrm{mm}$ length and 6-10 $\mathrm{mm}$ in diameter and are loosely imbedded in an arabinan matrix. The latter is partly present as a solid gel, partly woven tightly with the cellulose fibers (Malainine et al., 2003; Shedbalkar et al., 2010). Several beneficial functions have been ascribed to spines, including participation in zoochorous dispersal (Frego and Staniforth, 1985; Bobich and Nobel, 2001), mechanical protection from herbivores (Norman and Martin, 1986), shading of the stem (Nobel et al., 1986), collection of fog to absorb water (Ju et al., 2012), reflection of light (Loik, 


\section{T. HORIBE}

2008), and reduction in water loss (Stintzing and Carle, 2005). Edible Opuntia cultivars consumed as a vegetable have fewer spines than other Opuntia species, but these spines are very sharp, limiting the commercial value of this variety (Jacobo and Gallegos, 2017). Thus, spines on cladodes become one of the most undesirable characteristics of edible Opuntia for consumers. The spines are usually either burned or removed using a knife and/or machines before the cactus is put on sale (Jacobo and Gallegos, 2017).

\section{Root system}

Cacti generally have extensive and shallow root systems, spreading just below the soil surface, so that they can absorb water, even the relatively small amounts of water that moisten the soil surface during light rain showers. It has been reported that $95 \%$ of the roots of mature prickly pears develop at a soil depth of $40-470 \mathrm{~mm}$ and that the roots can spread as far as $2.5 \mathrm{~m}$ from the stem of the plant in 2 years (Nobel and De la Barrera, 2003; Snyman, 2006). Rain or watering after drought induce elongation of lateral root, which is also called "rain roots". They function for quick water absorption in soil, but tend to have short life (Dubrovsky and North, 2002). It has been reported that rain roots appear within 8 hours of watering in several cacti species including Opuntia (Kausch, 1965; Dubrovsky and North, 2002). Surface area of roots increase rapidly by the emergence of rain roots without a substantial increase in the distance for water transport (Dubrovsky and North, 2002).

\section{Mucilage}

Opuntia stems contain a large amount of mucilage, which constitutes approximately $14 \%$ of the dry weight of the cladodes (Ventura-Aguilar et al., 2017). Mucilage is a complex polysaccharide that is produced by specialized cells located in the cell wall. According to different reports, the monomers of the polysaccharide chain of mucilage from $O$. ficus-indica are L-arabinose:D-xylose, at a 2:1 ratio; L-rhamnose:galacturonicacidin, at an equimolar concentration; and D-galactose (Matsuhiro et al., 2006). In addition, the fraction of water-soluble polysaccharides with thickening properties consists essentially of pectin which form gels in the presence of $\mathrm{Ca}^{2+}$ (Majdoub et al., 2001; Sepúlveda et al., 2007; Ventura-Aguilar et al., 2017). Mucilage properties of $O$. ficus-indica has been evaluated by isolating pectin from the mucilage, and results indicated that $50 \%$ of mucilage composition was pectin (Bayar et al., 2016). Although molecular weight of mucilage and pectin are very similar $(52.8$ and $58.6 \mathrm{kDa}$, respectively); each one has different properties as soluble fiber. For example, mucilage showed $28 \%$ and $8 \%$ more water- and oil-holding capacities than pectin, respectively (Ventura-Aguilar et al., 2017). The plant mucilage forms molecular networks capable of retaining large amounts of water (Goldstein and Nobel, 1991; Sáenz et al., 2004). The physiological role of the mucilage is to regulate both the cellular water content during prolonged drought and the calcium fluxes of the plant (Rodríguez-García et al., 2007; Hernández-Urbiola et al., 2011).

The anatomical and physiological characteristics described above confer high resistance to drought and water retention in tissues, making edible Opuntia an important crop in the light of global desertification and declining water resources.

\section{USES OF EDIBLE OPUNTIA}

\section{Stem}

The main cultivated species produced as vegetables and forage are O. ficus-indica and Nopalea cochenillifera (Santos et al., 2016). O. ficus-indica has been selectively bred into many cultivars such as "Milpa Alta," "Atlixco," and "COPENA V1" (Jacobo and Gallegos, 2017). These cultivars grow faster and have fewer thorns and many other properties that are advantageous for both eating raw and processing. However, the size, color, and flexibility of stem nodes, the number and lengths of thorns, the resistance to heat, cold, and disease, and the pace of growth may vary depending on the type of cultivars. Edible Opuntia have a unique slimy mouthfeel caused by mucilage because of polysaccharides and acidity from a build-up of malic acid. The stem nodes can either be chopped up and made into salads after plucking the thorns or, as is done often, fried and added as a relish to meat dishes. The slimy properties of edible Opuntia make them a perfect fit with chicken and red meat, which tend to be dry and hard to swallow. Other species used as vegetables and fodder include $O$. robusta, O. streptacantha, O. leucotricha, O. hyptiacantha, O. chavena, O. megacantha, O. phaecantha, and O. atropes (Mizrahi et al., 1996). The stem of edible Opuntia is also used for processed food production. Processed food made using edible Opuntia includes water boils and pickles, but their use in most products involves crushing the Opuntia into powder and mixing them with other foods such as cookies, tortilla, candies, and beverages. The stem nodes of the Opuntia and crushed powder are used as raw materials for cosmetics, such as supplements, shampoo, soap, and sun screen. Additionally, food fiber extracted from the cacti may be used to make glue and adhesives (Sáenz, 2002; Stintzing and Carle, 2005).

The main constituent of $O$. ficus-indica cladodes is water $(80-95 \%)$, followed by small amounts of carbohydrates $\left(3^{-7 \%}\right)$, fiber $(1-2 \%)$, and protein $(0.5-1 \%)$; other compounds are only partly known and have not been determined quantitatively (Zhao et al., 2007). On a $100 \mathrm{~g}$ dry weight basis, it has been reported that the cladodes contain 64-71 g carbohydrates, $18 \mathrm{~g}$ fibers, 19-23.5 g ash, 1-4 g lipids, and 4-10 g proteins, the proteins consisting of 1-2 $\mathrm{g}$ digestive proteins (Retamal et al., 1987; Rodríguez-Felix and Cantwell, 1988; Yasseen et al., 1996; Mizrahi et al., 1996; Batista et al., 2003; Stintzing and Carle, 2005). However, cultivation environment including site, season, and age of the plant affects the cladode nutrient composition (Retamal et al., 1987; Rodríguez-Felix and Cantwell, 1988). Thus, the respective nutrient contents vary both among species and among varieties and should not be taken as absolute values. In some countries, Opuntia species are also used as remedies and folk medicine for various health problems, including burns, edema, and 
indigestion (Shetty et al., 2012; El-Mostafa et al., 2014). Edible Opuntia are known to contain several useful chemical compounds that have desirable nutritional and medicinal properties (Stintzing and Carle, 2005; Shedbalkar et al., 2010). Several reports have demonstrated their pharmaceutical actions, including their antioxidant, diuretic, anticarcinogenic, anti-inflammatory, anti-diabetic, and antihypercholesterolemic properties, in addition to their antiviral and antispermatogenic effects (Stintzing and Carle, 2005; Shetty et al., 2012; Ventura-Aguilar et al., 2017).

Opuntia cladodes serve as supplementary fodder for cows, sheep, and goats, especially in periods of severe drought in countries such as Brazil, Chile, California, Morocco, Mexico, South Africa, US and Tunisia (Stintzing and Carle, 2005). In addition to O. ficus-indica and $N$. cochenillifera under cultivation, wild Opuntia species, including $O$. cantabrigensis, O. lindheimeri, O. leucotricha, $O$. streptacantha, O. rastera, O. microdasys, O. pilifera, $O$. maxima, and $O$. robusta, are also used as forage (Stintzing and Carle, 2005). Opuntia plants are usually harvested in the dry season, when livestock feed is scarce. They are considered as being a component of the livestock diet throughout the year under intensive production systems, but a yearround supply of edible Opuntia is not common in most regions (Dubeux et al., 2017). Opuntia cladodes can supply a considerable amount of the animals' water requirements, although mineral and protein supplements are recommended with regard to diet composition due to the low dry matter content of the cladodes (Felker et al., 1997; Stintzing and Carle, 2005). It has been reported that lambs receiving a diet composed of $43 \%$ fresh cactus showed a $59 \%$ decrease in their water drinking (Gebremariam et al., 2006). Furthermore, Tegegne et al. (2007) reported that lambs stopped drinking water when there was access to a $55 \%$ fresh cactus-containing diet. Therefore, Opuntia plantations are a promising option for alleviating drinking water scarcity in dry areas and during drought periods. Several studies have shown other advantages of using Opuntia plants as forage. For example, low tannin and phenolic contents of Opuntia stems facilitate digestion and improve meat production (Nefzaoui and Salem, 2002; Tegegne, 2002). Russell and Felker (1987) reported that feeding Opuntia stems improves both the taste and the color of milk in domestic livestock.

The cladodes of edible Opuntia are commercially produced in more than 30 countries, and the crop cover of them is more than 100,000 ha worldwide. Areas where crops of edible Opuntia are found include the Mediterranean (Egypt, Italy, Greece, Spain, and Turkey), California, South America (Argentina, Brazil, Chile, Columbia, and Peru), the Middle East (Israel, Jordan), North Africa (Algeria, Morocco, and Tunisia), South Africa, and India (Felker et al., 1997; Singh, 2003; Stintzing and Carle, 2005). Mexico is the largest producer, with an acreage of 10,000 ha and an annual production volume exceeding $600,000 \mathrm{t}$. In Mexico, edible Opuntia grow in the wild over 300 million ha of land; fruits and stem nodes are also harvested from these wild Opuntia. Therefore, the actual production volume is thought to be even higher. In Japan, cacti are noth-

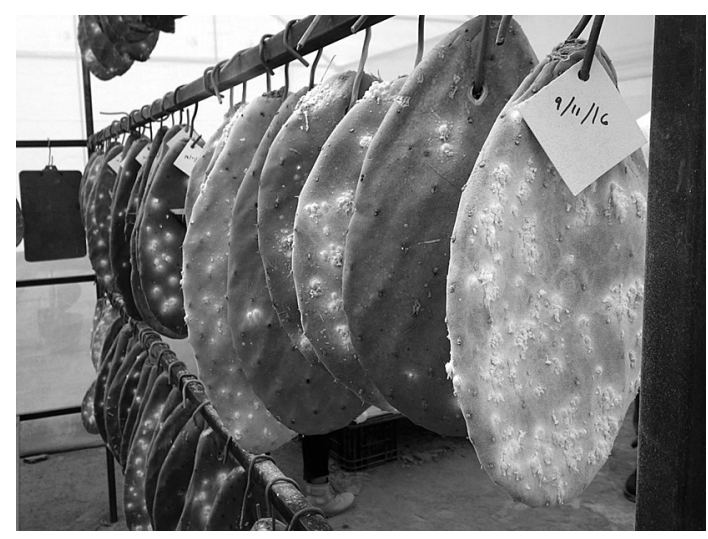

Fig. 3 Cocoons of Dactylopius spp. created on Opuntia cladodes. Insects live by sucking the fluids out of the stem nodes.

ing more than ornamental plants, and they are not generally recognized as being either vegetables or any other type of food, although Kasugai City in Aichi Prefecture produces edible Opuntia and makes use of them to advertise the city.

Another major use for edible Opuntia, besides as food, is dye production (Fig. 3). The dye is actually produced from the body fluids of parasitic insects, called Dactylopius spp., in the Opuntia. These parasites make a white cocoon on the stem nodes of the Opuntia, and they live by sucking the fluids out of the stem nodes. The parasites contain carminic acid in their fluids, and this turns deep red. Carminic acid is thought to function as a defensive substance for the parasite against predators, such as ants (Eisner et al., 1980). Until cheap aniline dye could be made from coal in the 19th century, dye made from Dactylopius spp. was the main source of red dye production. Although less is made nowadays, production still continues in places like Peru, Mexico, and the Canary Islands, and the dye is used in processed items, such as food and cosmetics, around the world (Stintzing and Carle, 2005).

Fruit

Most of the cactus fruits in the global market belong to the $O$. ficus-indica species and the fruits are sometimes called "cactus pear" or "tuna" (Fig. 4). The typical cactus

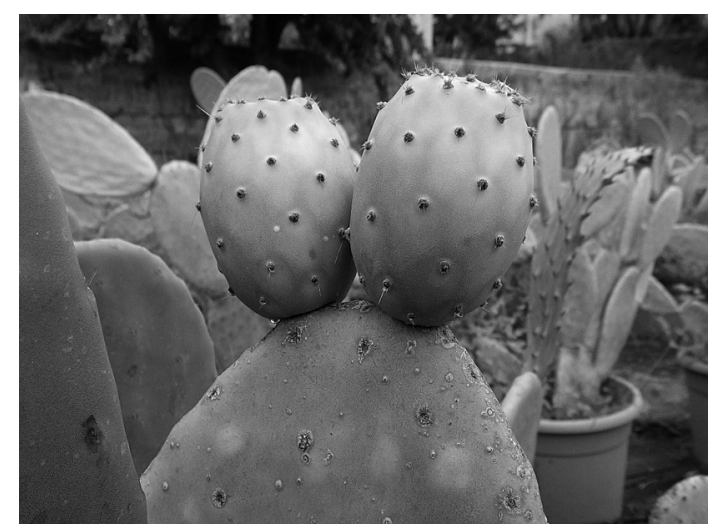

Fig. 4 Opuntia fruits at field in Palermo, Italy. They can either be consumed fresh or made into a variety of processed foods. 
Opuntia fruit is an oval-shaped berry with an average weight of $100-200 \mathrm{~g}$. The juicy pulp constitutes $60-70 \%$ of the total fruit weight and contains numerous small hard seeds, varying from 100 to over 400 per fruit (Potgieter and D'Aquino, 2017). Fruits are classified as non-climacteric, with no increase in respiratory or ethylene production with maturation (Cantwell, 1995). Various studies have examined the basic nutritional components of Opuntia fruit (El Kossori et al.,1998; Butera et al., 2002; Feugang et al., 2006). Sugars, fibre, mucilage and pectins are the major fruit constituents; proteins, amino acids, vitamins and minerals are the minor components (Tesoriere et al., 2005). Cactus pear is characterized by high sugar content (12$17 \%)$ and low acidity $(0.03-0.12 \%)$ with $\mathrm{pH}$ values between 5 and 7 . Moreover, total soluble solid content varies from 11.6 to $15.3^{\circ}$ Brix, increasing with fruit maturity (Yahia and Mondragón, 2011; Potgieter and D'Aquino, 2017). Opuntia fruits can be consumed either fresh, canned, or frozen, or they can be made into a variety of processed foods, including jams, jellies, sauces, marmalades, fruit sheets or rolls, powders, candies, syrups, purées, juices, vitamin water, and liquor (Cushman et al., 2015). Extracts of the fruit can be used as a natural food coloring because of their high betalain pigment content, and the fruits can also be fermented into a low-alcohol beverage called colonche (Sáenz, 2000; Cushman et al., 2015). Fruit production takes place in at least 18 countries in semiarid areas in both hemispheres on more than 100,000 ha (Inglese et al., 2002). These countries include Algeria, Argentina, Brazil, Chile, Colombia, Egypt, Greece, Italy, Israel, Jordan, Mexico, Morocco, Peru, Spain, South Africa, Tunisia, and Turkey (Potgieter and D'Aquino, 2017). However, little information is available regarding worldwide commercial plantations of Opuntia for fruit production. O. ficus-indica is the main species used for worldwide fruit production, although other species are grown in Mexico, including O. streptacantha, O. lindheimeri, O. amyclaea, O. megacantha, and O. robusta (Pimienta-Barrios and Muñoz-Urías, 1999).

\section{ALLEVIATING SOIL EROSION AND PHYTOREME- DIATION BY EDIBLE OPUNTIA}

Land erosion and degradation occur on all continents and affect the livelihoods of millions of people, including a large proportion of the poor in the drylands (Nefzaoui et al., 2014). Soils of arid and semi-arid zones are very susceptible to water erosion (Cornelis, 2006), due mostly to the scarce vegetation cover, low organic matter content, and consequent poor resistance to the forces of erosion. In these areas, severe soil erosion occurs rapidly after rainfall events. Erosion control in arid and semi-arid areas is another important use of cactus pear (Opuntia spp.), because of its rapid growth and widespread and shallow root system (Nobel and De la Barrera, 2003; Snyman, 2006). These cacti are also important as cover plants, because they can survive and spread under conditions of scarce rainfall and high temperatures, given their high resistance to drought and their ability to retain water in their tissues (Reynolds and Arias, 2001). Opuntia hedges play a major role in erosion control in North Africa. Most research and development projects in these areas aim at developing alternative technologies to reduce land degradation and favor sustainable economic activities (Shedbalkar et al., 2010). Margolis et al. (1985) reported that cacti cultivation has clear advantages in soil and water conservation compared with conventional land use. Furthermore, contour planting of Opuntia has been used to rehabilitate marginal lands in Tunisia and Algeria at low cost (Nefzaoui et al., 2012). Soil physical properties and organic matter content are improved under these cacti planting and in the immediate adjacent areas, with an improvement in organic matter and nitrogen compared with non-treated fields (Louhaichi et al., 2017). In this way, land degradation can be limited by planting Opuntia plants as a perennial crop for the production of cheap and drought-resistant sources of feed and biomass. Cacti might be a keystone species to help in controlling desertification and adapting to global warming from now on.

In recent years, phytoremediation, which is the use of plants to remove pollutants from the environment, has been proposed as a cost-effective and environmentally friendly measure for the restoration of soils contaminated by heavy metals (Palmer et al., 2001; Butcher 2009; Ojuederie and Babalola, 2017). Several studies have suggested that desert plants can be effective candidates for phytoremediation (Figueroa et al., 2007; Buendía-González et al., 2010; Adki et al., 2013); thus, Opuntia plants may be a good candidate for the phytoremediation of heavy metals in arid regions worldwide. The plants might be an efficient scavenger of pollutants since, being succulents, they very shallow and massive root systems that can spread out widely close to the soil surface and that are, thus, capable of effectively mining a large area of contaminated soil (Nobel and De la Barrera, 2003; Snyman, 2006; Shedbalkar et al., 2010). Several studies have investigated the heavy metal tolerance and heavy metal accumulation of cactus plants. Figueroa et al. (2007) reported that Opuntia (O. ficus-indica) can absorb $\mathrm{Pb}$ and $\mathrm{Cu}$ in the soil and that phytochelatins play a role in heavy metal absorption. Adki et al. (2013) reported that $N$. cochenillifera can accumulate large amounts of $\mathrm{Cr}$, making it a $\mathrm{Cr}$ hyperaccumulator (Adki et al., 2013). Furthermore, Horibe et al. (2019a; 2020) showed that $N$. cochenillifera can survive exposure to high concentrations of $\mathrm{Pb}, \mathrm{Zn}$, and $\mathrm{Cd}$ for more than 3 months under hydroponics condition, and that $N$. cochenillifera is also a $\mathrm{Zn}$ hyperaccumulator. The use of cacti to absorb and store toxic heavy metals and other organic pollutants in their cell systems would normally be safe, because grazing animals will generally avoid eating nonprocessed cacti; thus, as non-edible plants, such cacti would pose little danger of entering the food chain (Shedbalkar et al., 2010).

\section{CULTIVATION OF EDIBLE OPUNTIA}

\section{Agricultural practice}

The stem nodes used for fruits, vegetables and forage production are generally produced through vegetative 


\section{CACTUS AS CROP PLANT}

propagation. Edible Opuntia grow by building up new stem nodes (daughter cladode) on top of old ones (mother cladode). The daughter cladode is then cut off from the mother cladode, dried for approximately one week in a dark place, and used as a seedling for setting. As the size of the seedling has a strong impact on the subsequent generation and growth of the daughter cladode, it is preferable to use a stem node with either a surface area of $500 \mathrm{~cm}^{2}$ or above or a dried weight of 70 to $100 \mathrm{~g}$ or above (Potgieter and D'Aquino, 2017). When drying the extracted stem nodes, they should be placed standing vertically to prevent them from wilting. Sterilization of the stem nodes at this time is an effective way to prevent disease after setting. When setting, the stem nodes should be planted up to one third of their length. Setting them deep may reduce the surface area available for photosynthesis, whereas setting them shallow may cause them to wilt. Most edible Opuntia grow at a temperature of approximately $15-30^{\circ} \mathrm{C}$, and they are planted in either early spring or summer to facilitate favorable growth (Nobel and Bobich, 2002). One must be wary of a cold winter, since the plants may die at a temperature from $-10^{\circ} \mathrm{C}$ to $-5^{\circ} \mathrm{C}$ or less (Nobel and Bobich, 2002). In regions where the winter temperatures are very low, cultivation inside a greenhouse is recommended to avoid chilling injury.

The daughter cladode below the third division from the mother cladode (base) is usually collected at harvest. Above the third division, the plant body may be taller than a person, thereby slowing down the process of harvesting. The daughter cladode may contain too much fiber and become bitter when it grows, thus a younger stem node (generally within one month after generation) is selected for eating. Meanwhile, old lignified stem nodes may be crushed into powder and used for processing purposes. For the purpose of stem production (as a vegetable), O. ficusindica is ready for harvest when it reaches a length of approximately $15-20 \mathrm{~cm}$ and a fresh weight of approximately $90-100 \mathrm{~g}$, whereas $N$. cochenillifera is harvested at a length of approximately $11-13 \mathrm{~cm}$ and a fresh weight of approximately $40 \mathrm{~g}$ (Stintzing and Carle, 2005). The productivity of edible Opuntia (O. ficus-indica) stem is high, and the harvest volume can reach $30-80 \mathrm{t} \mathrm{ha}^{-1}$, or even $200 \mathrm{t} \mathrm{ha}^{-1}$ or more in farms with large collections (Mizrahi et al., 1996; Stintzing and Carle, 2005). In fruit production, yields are 2-8 $\mathrm{t} \mathrm{ha}^{-1}$ in most fields in Mexico (PimientaBarrios, 1994), but can reach 25 tha-1 in fields with irrigation (Gallegos-Vazques et al., 2009). The yield of fruits and stem is influenced by the climate of the land where the field is located, the cultivated varieties, the number of plants set in the field and how they are planted, as well as the presence of irrigation (Nerd et al., 1991; Inglese et al., 1995). With regard to production system, open-field production is the most common system in most countries (Jacobo and Gallegos, 2017). However, the harvest season in open-field is determined by the climate of field, especially by the duration of the frost-free period. Therefore, protected agriculture using plastic tunnels and greenhouse is sometimes applied to provide frost protection and beneficial temperature range $\left(10^{-} 30^{\circ} \mathrm{C}\right)$ for Opuntia growth. Mar- ket trends favoring out-of-season and year-round production result in increased product demand, benefiting both farmers and consumers.

Cultivation environment and Opuntia growth

The three key environmental factors affecting $\mathrm{CO}_{2}$ uptake of Opuntia plants are temperature, soil moisture (water) and solar irradiation (Nobel and Bobich, 2002). Nocturnal temperature strongly affects the daily pattern and the magnitude of total net $\mathrm{CO}_{2}$ uptake in $O$. ficus-indi$c a$, and photosynthetic productivity reach maximum with daylight temperatures of $25^{\circ} \mathrm{C}$ and nocturnal temperatures of $15^{\circ} \mathrm{C}$ (Nobel and Bobich, 2002). Although $\mathrm{CO}_{2}$ uptake occurs at $0^{\circ} \mathrm{C}$ and over $30^{\circ} \mathrm{C}$ in $O$. ficus-indica, higher day or lower night temperatures lead to sharp decrease in carbon assimilation, resulting in to poor plant growth, reduced production and eventually low crop value (Nobel and Loik, 1990; Nobel and Bobich, 2002). Temperatures over $30^{\circ} \mathrm{C}$ cause reductions of up to $70 \%$ in photosynthetic activity and affect fruit growth, leading to advanced and early ripening, and reduced fruit size, firmness and sugar content (Inglese et al., 2017). Meanwhile, daily temperatures below $15^{\circ} \mathrm{C}$ slow down fruit growth, delay fruit ripening time and result in thicker fruit peel and lower soluble sugar content as well as poor peel color (Nerd et al., 1991; Inglese et al., 1995; Liguori et al., 2006). Temperatures below $0^{\circ} \mathrm{C}$, even for 4 hours, conflict irreversible damage to the cladode tissue and the fruit. In addition, high temperatures (over 30/ $20^{\circ} \mathrm{C}$ day/night) produce more new cladodes than fruits, while lower temperature (below $20 / 15^{\circ} \mathrm{C}$ day/night) lead to lower number of rebudding (Nerd et al., 1991; Inglese et al., 1995; Liguori et al., 2006).

Water is continually being lost from the shoot of a plant to the atmosphere. Although Opuntia plants are characterized by high water use efficiency, the inevitable loss of stem water inhibits cellular processes that lead to $\mathrm{CO}_{2}$ uptake (Nobel and Bobich, 2002). In O. ficus-indica, it has been shown that net $\mathrm{CO}_{2}$ uptake of cladodes become around zero after 50 days of drought (Acevedo et al., 1983). In addition, 3 months of drought decrease nocturnal acid accumulation by $73 \%$, essentially abolish transpiration, and results in a decrease in the fresh weight of the parenchyma equal to $61 \%$, while the chlorenchyma lose only $27 \%$ of water (Acevedo et al., 1983; Goldstein and Nobel, 1991). Greater water loss in parenchyma seems to helps maintain nocturnal acid accumulation in the tissue of the chlorenchyma. The chlorenchyma of $O$. ficus-indica can reversibly lose $70 \%$ of its water content at full turgor, while the water storage parenchyma can lose $82 \%$ (Andrade et al., 2009). When rainfall occurs following a long dry period, re-watered cladodes show complete recovery in terms of fresh weight and gas exchange rate (Inglese et al., 2017).

Net $\mathrm{CO}_{2}$ uptake increases as the total daily photosynthetic photon flux (PPF) increases and it has been shown that PPF become half-maximal at about $13 \mathrm{~mol} \mathrm{~m}^{-2}$ day $^{-1}$, and become saturated at about $30 \mathrm{~mol} \mathrm{~m}^{-2}$ day $^{-1}$ (Nobel and Bobich, 2002). In the field, cladodes tend to be oriented to intercept more PPF and to have more net $\mathrm{CO}_{2}$ uptake, leading to more biomass productivity. Such cla- 


\section{T. HORIBE}

dode orientation is determined by the latitude of the plants and the timing of cladode initiation (Nobel and Bobich, 2002). For example, an east-west orientation tends to be favored for plants close to the equator because of the path of the sun in the sky. Cladode initiated during the summer tend to have an east-west orientation, while cladodes that are initiated during the winter face north-south (Nobel and Bobich, 2002). Since daughter cladodes of various Opuntia species tend to be oriented in the same direction as the underlying mother cladodes, orientation tendencies can be observed at the whole plant level (Nobel, 1982; Nobel and Bobich, 2002). Shading also affects fruit quality, depending on the extent of shading and sucrose exchange within the tree (Inglese et al., 2017). For instance, 15 days of imposed shade during earlier stages of fruit growth significantly affects fruit weight, but not the total soluble sugar content and ripening time (Inglese et al., 1999). This is in line with the fact that thinning is most effective in increasing fruit size when applied no later than 3 weeks after bloom (Inglese et al., 1995). Horibe et al. (2016) have evaluated the effects of red and blue LED light on the growth and spine occurrence in daughter cladodes. The productivity under simultaneous irradiation with red and blue light became higher than that of those under other treatments (Horibe et al., 2016). The number of spines on the cladodes was the highest on those treated with simultaneous irradiation with red and blue light and the lowest on those treated with red light alone (Horibe et al., 2016). These results showed that light wavelength has a strong effect on cladode growth and morphology of edible Opuntia.

Since temperature, soil moisture (water) and solar irradiation (light) greatly affect growth and productivity of edible Opuntia as mentioned above, environmental control of these conditions inside greenhouse would improve productivity and quality of this crop although such environmental control is not widely conducted.

Application of hydroponics in edible Opuntia cultivation

The main problems encountered in growing vegetables in soil include soil-borne disease, salt accumulation, and difficulty in fertilizer management (Lakkireddy et al., 2012). In hydroponic culture, plants are grown using nutrient solution (water and fertilizer), with or without the use of an artificial medium. Such a system can avoid the costly and time-consuming task of soil sterilization to prevent soil-borne disease, and enable precise fertilizer management (Wahome et al., 2011; Lakkireddy et al., 2012), resulting in numerous advantages for consumers as well as producers. Hydroponics is also effective in modifying the nutrient composition of vegetables. Nitrogen is an essential element for plant growth, and nitrate is one of the available forms of nitrogen for plant uptake. Nitrate itself is relatively non-toxic, but it can be converted to harmful nitrites post-harvest, and high human intake of nitrate may produce a number of health problems (Santamaria, 2005). In hydroponics, several methods have been established to reduce the nitrate content of vegetables (Wang et al., 2007; Stefanelli et al., 2011). Ogawa et al. (2012) reported meth- ods for cultivating leafy vegetables and tomatoes with low potassium content for dialysis patients, in whom potassium intake is restricted. In addition, precise salinity control in hydroponic tomato cultivation has also been reported to improve fruit quality (Sakamoto et al., 1999). Thus, there are advantages associated with hydroponic culture that could be exploited for cultivation of edible Opuntia.

Edible Opuntia can be successfully grown by hydroponics although it is usually grown by outdoor cultivation (soil cultivation) under mainly arid and semi-arid climate (Horibe and Yamada, 2016). Horibe (2017) investigated the effect of hydroponic culture involving the deep flow technique (DFT) on the productivity of edible Opuntia by comparing the cladode growth between DFT and pot culture (soil culture), and it became higher in DFT than in pot culture, showing the effectiveness of DFT in edible Opuntia production (Horibe, 2017). Ramírez-Tobías et al. (2010) also reported effectiveness of hydroponics in Opuntia production. They evaluated the effect of hydroponics using pot culture and irrigation with nutrient solution on growth of Opuntia species, and yield in their experiment reached $142-470 \mathrm{t} \mathrm{ha}^{-1}$, which is much larger than average yield (30-80 $\mathrm{t} \mathrm{ha}^{-1}$ ) reported in open-field in Mexico (Mizrahi et al., 1996; Stintzing and Carle, 2005).

Several studies suggested that hydroponics also affected other aspects of edible Opuntia as well as productivity. Horibe and Yamada (2016) investigated the effects of DFT on the growth of edible Opuntia, and its effect on spine development on daughter cladodes. When given the drought stress for edible Opuntia grown by pot culture, the length of first daughter cladodes in low drought stress was longest, followed by middle drought stress, high drought stress. Then, spine occurrence on daughter cladodes in hydroponics and pot cultures was compared. It was the highest in cladodes under high drought stress and the lowest under DFT (Horibe and Yamada, 2016). This result suggests that water availability for mother cladodes affects the development of spines on daughter cladodes. Since the spines on cladodes are one of the most undesirable characteristics in edible Opuntia, it seems that hydroponics is effective to overcome the issue of spines and their reduction of the commercial value of edible Opuntia. Horibe et al. (2020) reported Zn biofortification of edible cactus $N$. cochenillifera using hydroponics as a way to address $\mathrm{Zn}$ deficiency. $N$. cochenillifera accumulated $>80 \mathrm{mg} \mathrm{kg}^{-1}$ fresh weight of $\mathrm{Zn}$ in the daughter cladodes and $\mathrm{Zn}$ concentration in plant was much greater than the threshold of $\mathrm{Zn}$ hyperaccumulation plants (Horibe et al., 2020). Furthermore, the effects of light environment control in enclosed-type plant factory on the growth and quality of $N$. cochenillifera grown under hydroponics were investigated (Horibe et al., 2016; 2019b). Results showed that light wavelength affected the amount of harvest, radical scavenging activity and spine growth of cladodes (Horibe et al., 2016; 2019b), meaning that productivity and quality of edible cacti can be enhanced using precise environmental control.

Edible Opuntia have many features that make them suitable for production in green house as well as plant fac- 


\section{CACTUS AS CROP PLANT}

tories, such as their rapid growth and ability to be vegetatively propagated through the stems (in the short term until harvest). In addition, the cladodes can be planted at a high density on cultivation panels resulting in effective use of the available space, and can be grown under relatively low light intensity using artificial light (Horibe et al., 2016). Although open-field cultivation is current mainstream in edible Opuntia production, hydroponics and environmental control in green house as well as plant factory might be powerful tools to improve their productivity and quality and promote its utilization.

\section{CONCLUSIONS}

In this review, we described physiological features, recent uses and cultivation of edible Opuntia. Edible Opuntia have many characteristics as a model plant for deciphering the mechanisms of their special properties. These include their high resistance to drought, ability to retain water in body tissues and heavy metal tolerance. With these special physiological features, Opuntia plants became good candidate for phytoremediation and soil erosion control. Elucidation of these physiological features would contribute to solve environmental problems as well as greatly advance basic scientific knowledge regarding plant biology. Furthermore, Opuntia plants are also hopeful crop for achieving sustainable production to meet the growing demand for food and as a new source for satisfying health requirements. In a time when global warming and population growth requires an urgent response, demands and importance of edible Opuntia will grow even more in the future.

\section{REFERENCES}

Acevedo, E., Badilla, I., Nobel, P. S. 1983. Water relations, diurnal activity changes, and productivity of a cultivated cactus Opuntia ficus-indica. Plant Physiol. 72: 775-780.

Adki, V. S., Jadhav, J. P., Bapat, V. A. 2013. Nopalea cochenillifera, a potential chromium (VI) hyperaccumulator plant. Environ. Sci. Pollut. Res. 20: 1173-1180.

Anderson, E. F. 2001. The cactus family. Timber Press, Portland, USA, pp 776.

Andrade, J. L., Cervera, J. C., Graham, E. A. 2009. Microenvironments, water relations, and productivity of CAM plants. In "Perspectives in Biophysical Plant Ecophysiology: A Tribute to Park S. Nobel" (ed. by de la Barrera, E., Smith, W.), UNAM, Mexico City, Mexico, p 95-120.

Bailey, I. W. 1964. Comparative anatomy of the leaf bearing Cactaceae, VI: The xylem of Pereskiopsis and Quiabentia. Journal of the Arnold Arboretum 45: 140-157.

Barthlott, W., Hunt, D. R. 1993. Cactaceae. In "The Families and Genera of Vascular Plants" (ed. by Kubitzki, K.), SpringerVerlag, New York, USA, p 161-197.

Batista, A. M., Mustafa, A. F., McAllister, T.,Wang, Y., Soita, H., McKinnon, J. J. 2003. Effects of variety on chemical composition, in situ nutrient disappearance and in vitro gas production of spineless cacti. J. Sci. Food Agric. 83: 440-445.

Bayar, N., Kriaa, M., Kammoun, R. 2016. Extraction and characterization of three polysaccharides extracted from Opuntiaficusindica cladodes. Int. J. Biol. Macromol. 92: 441-450.

Bobich, E. G., Nobel, P. S. 2001. Vegetative reproduction as re- lated to biomechanics, morphology and anatomy of four cholla cactus species in the Sonoran Desert. Ann. Bot. 87: 485-493.

Boke, N. H. 1952. Leaf and areole development in Coryphantha. Am. J. Bot. 39: 134-145.

Boke, N. H. 1953. Tubercle development in Mammillaria heyderi. Am. J. Bot. 40: 239-247.

Boke, N. H. 1955. Dimorphic areoles of Epithelantha. Am. J. Bot. 42: 725-733.

Boke, N. H. 1958. Areole histogenesis in Mammillaria lasiacantha. Am. J. Bot. 45: 473-479.

Boke, N. H. 1961. Areole dimorphism in Coryphantha. Am. J. Bot. 48: 593-603.

Boke, N. H. 1980. Developmental morphology and anatomy in Cactaceae. BioScience 30: 605-610.

Bravo, H. 1978. Las Cactáceas de México. Ed 2. UNAM, Mexico City, Mexico, pp 743.

Buendía-González, L., Orozco-Villafuerte, J., Cruz-Sosa, F., Barrera-Díaz, C. E., Vernon-Carter, E. J. 2010. Prosopis laevigata a potential chromium (VI) and cadmium (II) hyperaccumulator desert plant. Biores. Technol. 101: 5862-5867.

Butcher, D. J. 2009. Phytoremediation of lead in soil: recent applications and future prospects. Appl. Spectrosc. Rev. 44: 123-139.

Butera, D., Tesoriere, L., Di Gaudio, F., Bongiorno, A., Allegra, M., Pintaudi, A. M., Kohen, R., Livrea, M. A. 2002. Antioxidant activities of Sicilian prickly pear (Opuntia ficus-indica) fruit extracts and reducing properties of its betalains: betanin and indica-xanthin. J. Agric. Food Chem. 50: 68956901.

Cantwell, M. 1995. Post-harvest management of fruits and vegetable stems. In "Agro-Ecology, Cultivation and Uses of Cactus Pear" (ed. by Barbera, G., Inglese, P., Pimienta-Barrios, E.), FAO Plant Production and Protection Paper No. 132. Rome, Italy, p 120-141.

Conde, L. F. 1975. Anatomical comparisons of five species of Opuntia (Cactaceae). Ann. Mo. Bot. Gard. 62: 425-473.

Cornelis, W. M. 2006. Hydroclimatology of wind erosion in arid and semiarid environments. In "Dryland Ecohydrology" (ed. by D'Odorico, P., Porporato, A.), Springer, Netherlands, p 141-159.

Cruz-Hernández, A., Paredes-López, O. 2010. Enhancement of economical value of nopal and its fruits through biotechnology. J. PACD 12: 110-126.

Cushman, J. C., Bohnert, H. J. 1999. Crassulacean acid metabolism: molecular genetics. Ann. Rev. Physiol. Plant Mol. Biol. 50: 305-332.

Cushman, J. C., Davis, S. C., Yang, X., Borland, A. M. 2015. Development and use of bioenergy feedstocks for semi-arid and arid lands. J. Exp. Bot. 66: 4177-4193.

Drennan P. M., Nobel, P. S. 2000. Responses of CAM species to increasing atmospheric $\mathrm{CO}_{2}$ concentration. Plant, Cell and Environ. 23: 767-781

Dubeux, Jr. C. B., Salem, H. B., Nefzaoui, A. 2017. Forage production and supply for animal nutrition. In "Crop Ecology Cultivation and Uses of Cactus Pear" (ed. by Inglese, P., Mondragon, C., Nefzaoui, A., Sáenz, C.), Food and Agriculture Organization of the United Nations and the International Center for Agricultural Research in the Dry Areas, Rome, Italy, p 73-92.

Dubrovsky, J. G., North, G. B. 2002. Root structure and function. In "Cacti. Biology and Uses" (ed. by Nobel, P. S.), University of California Press, Berkeley, USA, p 41-56.

El Kossori, R.L., Villanume, C., El Boustani, E., Sauvaire, Y., Mejean, L. 1998. Composition of pulp, skin and seeds of prickly pears fruit (Opuntia ficus-indica sp.). Plant Foods Hum. Nutr. 52: 263-270. 
El-Mostafa, K., El-Kharrassi, Y., Badreddine, A., Andreoletti, P., Vamecq, J., El-Kebbaj, M. S., Latruffe, N., Lizard, G., Nasser, B., Cherkaoui-Malki, M. 2014. Nopal cactus (Opuntia ficus-indica) as a source of bioactive compounds for nutrition, health and disease. Molecules 19: 14879-14901.

Eisner, T., Nowicki, S., Goetz, M., Meinwald, J. 1980. Red cochineal dye (carminic acid): its role in nature. Science 208: 1039-1042.

Fahn, A. 1986. Structural and functional properties of trichomes of xeromorphic leaves. Ann. Bot. 57: 631-637.

Felker, P., Singh, G., Pareek, O. P. 1997. Opportunities for development of cactus (Opuntia spp.) in arid and semi-arid regions. Ann. Arid Zone 36: 267-278.

Feugang, J.M., Konarski, P., Zou, D., Stintzing, F. C., Zou, C. 2006. Nutritional and medicinal use of cactus (Opuntia spp.) cladodes and fruits. Front. Biosci. 11: 2574-2589.

Figueroa, J. A. L., Afton, S., Wrobel, K., Wrobelac, K., Caruso, J. A. 2007. Analysis of phytochelatins in nopal (Opuntia ficus): a metallomics approach in the soil-plant system. J. Anal. At. Spectrom. 22: 897-904.

Frego, K. A., Staniforth, R. J. 1985. Factors determining the distribution of Opuntia fragilis in the boreal forest of southeastern Manitoba. Can. J. Bot. 63: 2377-2382.

Gallegos-Vazques, C., Mondragon-Jacobo, C., Reyes-Aguero, J. A. 2009. An update on the evolution of the cactus pear industry in Mexico. Acta Hortic. 811: 69-76.

García-Saucedo, P. A., Valdez-Morales, M., Valverde, M. E., Cruz-Hernández, A., Paredes-López, O. 2005. Plant regeneration of three Opuntia genotypes used as human food. Plant Cell Tissue Organ Cult. 80: 215-219.

Gebremariam, T., Melaku, S., Yami, A. 2006. Effect of different levels of cactus (Opuntia ficus-indica) inclusion on feed intake, digestibility and body weight gain in tef (Eragrostis tef) straw-based feeding of sheep. Anim. Feed Sci. Technol. 131: 41-52.

Gibson, A. C. 1978. Wood anatomy of platyopuntias. Aliso 9: 279-303.

Gibson, A. C., Nobel, P. S. 1986. The Cactus Primer. Harvard University Press, Cambridge, Massachusetts, USA, pp 286.

Goldstein, G., Nobel, P. S. 1991. Changes in osmotic pressure and mucilage during low-temperature acclimation of Opuntia ficus-indica. Plant Physiol. 97: 954-961.

Guzmán-Maldonado, S. H, Paredes-López, O. 1999. Biotechnology for the improvement of nutritional quality of food crop plants. In "Molecular Biotechnology for Plant Food Production" (ed. by Paredes-López, O.), CRC Press, Boca Raton, USA, p 553-620.

Hernández-Urbiola, M. I., Pérez-Torrero, E., Rodríguez-García, M. E. 2011. Chemical analysis of nutritional content of prickly pads (Opuntia ficus-indica) at varied ages in an organic harvest. Int. J. Environ. Res. Public Health 8: 1287-1295.

Horibe, T., Yamada, K. 2016. Hydroponics culture of edible Opuntia 'Maya': drought stress affects the development of spines on daughter cladodes. Environ. Control Biol. 54: 153156.

Horibe, T., Iwagaya, Y., Kondo, H., Yamada, K. 2016. Hydroponics culture of edible Opuntia 'Maya': effect of constant red and blue lights on daughter cladodes growth and spine development. Environ. Control Biol. 54: 165-169.

Horibe, T. 2017. A cost-effective, simple, and productive method of hydroponic culture of edible Opuntia "Maya". Environ. Control Biol. 55: 171-174.

Horibe, T., Sumi, H., Imai, S., Matsuoka, T. 2019a. Effects of heavy metals on the growth of the edible cactus Nopalea cochenillifera grown under hydroponic conditions. Environ. Control Biol. 57: 9-13.
Horibe, T., Imai, S., Matsuoka, T. 2019b. Effects of light wavelength on daughter cladode growth and quality in edible cactus Nopalea cochenillifera cultured in a plant factory with artificial light. J. Hortic. Res. 26: 71-80.

Horibe, T., Sumi, H., Teranobu, R. 2020. Zinc biofortification of the edible cactus Nopalea cochenillifera grown under hydroponic conditions. Environ. Control Biol. 58: 43-47.

Hunt, D., Taylor, N. P., Charles, G. 2006. The new cactus lexicon. dh Books, Milborne Port, UK, pp 527.

Inglese, P., Barbera, G., La Mantia, T., Portolano, S. 1995. Crop production, growth and ultimate fruit size of cactus pear following fruit thinning. HortScience 30: 227-230.

Inglese, P., Barbera, B., La Mantia, T. 1999. Seasonal reproductive and vegetative growth patterns, and resource allocation during cactus pear Opuntia ficus-indica (L.) Mill. fruit growth. HortScience 34: 69-72.

Inglese, P., Gugluizza, G., La Mantia, T. 2002. Alternate bearing and summer pruning of cactus pear. Acta Hortic. 581: 201204.

Inglese, P., Liguori, G., de la Barrera, E. 2017. Ecophysiology and reproductive biology of cultivated cacti. In "Crop Ecology Cultivation and Uses of Cactus Pear" (ed. by Inglese, P., Mondragon, C., Nefzaoui, A., Sáenz, C.), Food and Agriculture Organization of the United Nations and the International Center for Agricultural Research in the Dry Areas, Rome, Italy, p 29-42.

Jacobo, C. M., Gallegos, S. J. M. 2017. Nopalitos or vegetable cactus production and utilization. In "Crop Ecology Cultivation and Uses of Cactus Pear" (ed. by Inglese, P., Mondragon, C., Nefzaoui, A., Sáenz, C.), Food and Agriculture Organization of the United Nations and the International Center for Agricultural Research in the Dry Areas, Rome, Italy, p 93-104.

Juárez, M. C., Passera, C. B. 2002. In vitro propagation of Opuntia ellisiana Griff. and acclimatization to field conditions. Biocell 26: 319-324.

Ju, J., Bai, H., Zheng, Y., Zhao, T., Fang, R., Jiang, L. A. 2012. A multi-structural and multi-functional integrated fog collection system in cactus. Nat. Commun. 3: 1247.

Kausch, W. 1965. Beziehungen zwischen Wurzelwachstum, Transpiration und $\mathrm{CO}_{2}$-Gaswechsel bei einigen Kakteen. (in German with English summary) Planta 66: 229-238.

Lakkireddy, K. K. R., Kasturi, K., Sambasiva, Rao, R. K. S. 2012. Role of hydroponics and aeroponics in soilless culture in commercial food production. JAST 1: 26-35.

Le Houerou, H. N. 2000. Utilization of fodder trees and shrubs in the arid and semiarid zones of West Asia and North Africa. Arid Soil Res. Rehabil. 14: 101-135.

Liguori, G., Di Miceli, C., Gugluizza, G., Inglese, P. 2006. Physiological and technical aspects of cactus pear [Opuntia ficus-indica (L.) Mill.] double reflowering and out-of-season winter fruit cropping. Int. J. Fruit Sci. 6: 23-34.

Loik, M. E. 2008. The effect of cactus spines on light interception and Photosystem II for three sympatric species of Opuntia from the Mojave Desert. Physiol. Plant. 134: 87-98.

Louhaichi, M., Nefzaoui, A., Guevara, J. C. 2017. Cactus ecosystem goods and services. In "Crop Ecology Cultivation and Uses of Cactus Pear" (ed. by Inglese, P., Mondragon, C., Nefzaoui, A., Sáenz, C.), Food and Agriculture Organization of the United Nations and the International Center for Agricultural Research in the Dry Areas, Rome, Italy, p 159-170.

Lüttge, U. 2004. Ecophysiology of crassulacean acid metabolism (CAM). Ann. Bot. 93: 629-652.

Majdoub, H., Roudesli, S., Picton, L., Le Cerf, D., Muller, G., Grisel, M. 2001. Prickly pear nopals pectin from Opuntia ficus indica physico-chemical study in dilute and semi-dilute solutions. Carbohydr. Polym. 46: 69-79. 


\section{CACTUS AS CROP PLANT}

Malainine, M. E., Dufresne, A., Dupeyre, D., Mahrouz, M., Vuong, R., Vignon, M. R. 2003. Structure and morphology of cladodes and spines of Opuntia ficus-indica. Cellulose extraction and characterization. Carbohydr. Polym. 51: 77-83.

Margolis, E., Silva, A. B., Jacques, F. O. 1985. Determinação dos fatores da Equação Universal de Perdas de Solo para as condições de Caruaru (PE). (in Portuguese with English summary) Rev. Bras. Ciênc. Solo. 9: 165-169.

Matsuhiro, B., Lillo, L., Saenz, C., Urzúa, C., Zárate, O. 2006 Chemical characterization of the mucilage from fruits of Opuntia ficus-indica. Carbohydr. Polym. 63: 263-267.

Mauseth, J. D. 1976. Cytokinin- and gibberellic acid-induced effects on the structure and metabolism of shoot apical meristems in Opuntia polyacantha (Cactaceae). Am. J. Bot. 63 1295-1301.

Mauseth, J. D. 1995. Collapsible water-storage cells in cacti. Bull. Torrey Bot. Club 122: 145-151.

Mauseth, J. D. 1996. Comparative anatomy of tribes Cereeae and Browningieae (Cactaceae). Bradleya 14: 66-81.

Mauseth, J. D. 1999. Anatomical adaptations to xeric conditions in Maihuenia (Cactaceae), a relictual, leaf-bearing cactus. J. Plant Res. 112: 307-315.

Mauseth, J. D. 2006. Structure-function relationship in highly modified shoots of Cactaceae. Ann. Bot. 98: 901-926.

Mauseth, J. D., Landrum, J. V. 1997. Relictual vegetative anatomical characters in Cactaceae: The genus Pereskia. J. Plant Res. 110: 55-64.

Metzing, D., Kiesling, R. 2008. The study of cactus evolution: the pre-DNA era. Haseltonia 14: 6-25.

Mizrahi, Y., Nerd, A., Nobel, P. S. 1996. Cacti as crops. Hortic Rev. 18: 291-320.

Monson, R. K. $\quad 1989 . \quad$ On the evolutionary pathways resulting in $\mathrm{C}_{4}$ photosynthesis and crassulacean acid metabolism (CAM). Adv. Ecol. Res. 19: 57-110.

Nefzaoui, A., Salem, H. B. 2002. Forage, fodder, and animal nutrition. In "Cacti. Biology and Uses" (ed. by Nobel, P. S.), University of California Press, Berkeley, USA, p 199-210.

Nefzaoui, A., Ketata, H., El Mourid, M. 2012. Agricultural technological and institutional innovations for enhanced adaptation to environmental change in North Africa. In "International Perspectives on Global Environmental Change" (ed. by Young, S. S., Silvern, S. E.), InTech, London, UK, p 57-84.

Nefzaoui, A., Louhaichi, M., Salem, H. B. 2014. Cactus as a tool to mitigate drought and to combat desertification. J. Arid Land Stud. 24: 121-124.

Nerd, A., Karadi, A., Mizrahi, Y. 1991. Out-of-season prickly pear: fruit characteristics and effect of fertilisation and short droughts on productivity. HortScience 26: 527-529.

Nobel, P. S. 1982. Orientation, PAR interception, and nocturnal acidity increases for terminal cladodes of a widely cultivated cactus, Opuntia ficus-indica. Am. J. Bot. 69: 1462-1469.

Nobel, P. S. 1999. Physicochemical and Environmental Plant Physiology. Ed. 2. Academic Press, San Diego, Californa, USA, pp 604

Nobel, P. S., Geller, G. N., Kee, S. C., Zimmerman, A. D. 1986 Temperatures and thermal tolerances for cacti exposed to hightemperatures near the soil surface. Plant Cell Environ. 9: 279287.

Nobel, P. S., Loik, M. E. 1990. Thermal analysis, cell viability, and $\mathrm{CO}_{2}$ uptake of a widely distributed North American cactus, Opuntia humifusa, at subzero temperatures. Plant Physiol. Biochem. 28: 429-436.

Nobel, P. S., De la Barrera, E. 2000. Carbon and water balances for young fruits of platyopuntia. Physiol. Plant. 109: 160-166.

Nobel, P. S., De la Barrera, E. 2003. Tolerances and acclimation to low and high temperatures for cladodes, fruits and roots of a widely cultivated cactus, Opuntia ficus-indica. New Phytol. 157: 271-279.

Nobel, P. S., Bobich, E. G. 2002. Environmental biology. In "Cacti. Biology and Uses" (ed. by Nobel, P. S.), University of California Press, Berkeley, USA, p 57-74.

Norman, F., Martin, C. E. 1986. Effects of spine removal on Coryphantha vivipara in central Kansas. Am. Midl. Nat. 116: $118-124$.

Nyffeler, R. 2002. Phylogenetic relationships in the cactus family (Cactaceae) based on evidence from trnK/matK and trnL-trnF sequences. Am. J. Bot. 89: 312-326.

Ogawa, A., Eguchi, T., Toyofuku, K. 2012. Cultivation methods for leafy vegetables and tomatos with low potassium content for dialysis patients. Environ. Control Biol. 50: 407-414.

Ojuederie, O. B., Babalola, O. O. 2017. Microbial and plant-assisted bioremediation of heavy metal polluted environments: a review. Int. J. Environ. Res. Public. Health 14: 1504

Osmond, C. B. 1978. Crassulacean acid metabolism: a curiosity in context. Annu. Rev. Plant Physiol. 29: 379-414.

Palmer, C. E., Warwick, S., Keller, W. 2001. Brassicaceae (Cruciferae) family, plant biotechnology, and phytoremediation. Int. J. Phytorem. 3: 245-287.

Pimienta-Barrios, E., Loera-Quezada, M., López-Amezcua, L. 1993. Estudio anatómico comparativo en colectas del subgénero Opuntia. Agrociencia series Fitociencia 4: 7-14.

Pimienta-Barrios, E. 1994. Prickly pear (Opuntia spp.): a valuable fruit crop for the semiarid lands of Mexico. J. Arid Environ. 28: 1-11

Pimienta-Barrios, E., Muñoz-Urías, A. 1999. Domesticacion de nopales tuneros (Opuntia spp.) y descripcion de las principales variedades cultivadas. In "Agroecologia, Cultivo y Usos del Nopal” (ed. by Barbera, G., Inglese, P., Pimienta-Barrios, E.), FAO Plant Production and Protection Paper 132. Rome, Italy, p 61-67.

Pimienta-Barrios, E., Zañudo-Hernandez, J., Rosas-Espinoza, V C., Valenzuela-Tapia, A., Nobel, P. S. $2005 . \quad$ Young daughter cladodes affect $\mathrm{CO}_{2}$ uptake by mother cladodes of Opuntia ficus-indica. Ann. Bot. 95: 363-369.

Potgieter, J., D’Aquino, S. 2017. Fruit production and post-harvest management. In "Crop Ecology Cultivation and Uses of Cactus Pear" (ed. by Inglese, P., Mondragon, C., Nefzaoui, A., Sáenz, C.), Food and Agriculture Organization of the United Nations and the International Center for Agricultural Research in the Dry Areas, Rome, Italy, p 51-72.

Pritchard, H. N., Hall, J. A. 1976. The chemical composition of glochids from Opuntia. Can. J. Bot. 54: 173-176.

Ramírez-Tobías, H. M., Aguirre-Rivera, J. R., Pinos-Rodríguez, J. M., Reyes-Agüero, J. A. 2010. Nopalito and forage productivity of Opuntia spp. and Nopalea sp. (Cactaceae) growing under greenhouse hydroponics system. J. Food Agric. Environ. 8: 660-665.

Rebman, J. P., Pinkava, D. J. 2001. Opuntia cacti of north America: an overview. Florida Entomol. 84: 474-483.

Retamal, N., Durán, J. M., Fernández, J. 1987. Seasonal variations of chemical composition in prickly pear (Opuntia ficusindica (L.) Miller). J. Sci. Food Agric. 38: 303-311.

Reynolds, S. G., Arias, E. 2001. Introduction. In "Cactus (Opuntia spp.) as Forage" (ed. by Mondragón Jacobo, C., Pérez González, S), FAO Plant Production and Protection Paper No. 169. Rome, Italy, p 1-4

Rodríguez-Felix, A., Cantwell, M. 1988. Developmental changes in composition and quality of prickly pear cactus cladodes (nopalitos). Plant Foods Hum. Nutr. 38: 83-93.

Rodríguez-García, M. E., De Lira, C., Hernández-Becerra, E., Cornejo-Villegas, M. A., Palacios-Fonseca, A. J., RojasMolina, I., Reynoso, R., Quintero, L. C., Del-Real, A., Zepeda, 


\section{T. HORIBE}

T. A., Muñoz-Torres, C. 2007. Physicochemical characterization of prickly pads (Opuntia ficus indica) and dry vacuum prickly pads powders as a function of the maturation. Plant Foods Hum. Nutr. 62: 107-112.

Russell, C. E., Felker, P. $\quad$ 1987. The prickly pears (Opuntia spp., Cactaceae), a source of human and animal food in semiarid regions. Econ. Bot. 41: 433-445.

Sáenz, C. 2000. Processing technologies: an alternative for cactus pear (Opuntia spp.) fruits and cladodes. J. Arid Environ. 46: 209-225.

Sáenz, C. 2002. Cactus pear fruit and cladodes: a source of functional components for foods. Acta Hortic. 581: 253-263.

Sáenz, C., Sepúlveda, E., Matsuhiro, B. 2004. Opuntia spp. mucilages: A functional component with industrial perspectives. J. Arid Environ. 57: 275-290.

Sakamoto, Y., Watanabe, S., Nakashima, T., Okano, K. 1999. Effects of salinity at two ripening stages on the fruit quality of single-truss tomato grown in hydroponics. J. Hortic. Sci. Biotechnol. 74: 690-693.

Salgado, T. T., Mauseth, J. D. 2002. Shoot anatomy and morphology. In "Cacti. Biology and Uses" (ed. by Nobel, P. S.), University of California Press, Berkeley, USA, p 23-40.

Sánchez, D., Grego-Valencia, D., Terrazas, T., Arias, S. 2015. How and why does the areole meristem move in Echinocereus (Cactaceae)? Ann. Bot. 115: 19-26.

Santamaria, P. 2005. Nitrate in vegetables: toxicity, content, intake and EC regulation. J. Sci. Food Agric. 86: 10-17.

Santos, T. do N., Dutra, E. D., Prado, A. G. do, Leite, F. C. B., Souza, R. de F. R. de, Santos, D. C. dos, Abreu, C. A. M. de, Simões, D. A., Morais Jr, M. A. de, Menezes, R. S. C. 2016. Potential for biofuels from the biomass of prickly pear cladodes: Challenges for bioethanol and biogas production in dry areas. Biomass Bioenergy 85: 215-222.

Sepúlveda, E., Sáenz, C., Aliaga, E., Aceituno, C. 2007. Extraction and characterization of mucilage in Opuntia spp. J. Arid Environ. 68: 534-545.

Shedbalkar, U. U., Adki,V. S., Jadhav, J. P., Bapat, V. A. 2010. Opuntia and other cacti: applications and biotechnological insights. Trop. Plant Biol. 3: 136-150.

Shetty, A. A., Rana, M. K., Preetham, S. P. 2012. Cactus: a medicinal food. J. Food Sci. Technol. 49: 530-536.

Silos-Espino, H., Valdez-Ortiz, A., Rascón-Cruz, Q., RodríguezSalazar, E., Paredes-López, O. 2006. Genetic transformation of prickly-pear cactus (Opuntia ficus-indica) by Agrobacterium tumefaciens. Plant Cell Tissue Organ Cult. 86: 397-403.

Singh, G. 2003. General review of Opuntias in India. J. PACD 5: $30-46$.

Snyman, H. A. 2006. Root distribution with changes in distance and depth of two-year old cactus pear Opuntia ficus-indica and O. robusta plants. S. Afr. J. Bot. 72: 434-441.

Stefanelli, D., Winkler, S., Jones, R. 2011. Reduced nitrogen availability during growth improves quality in red oak lettuce leaves by minimizing nitrate content, and increasing antioxidant capacity and leaf mineral content. Agric. Sci. 2: 477-486.

Stintzing, F. C., Carle, R. 2005. Cactus stems (Opuntia spp.): a review on their chemistry, technology, and uses. Mol. Nutr. Food Res. 49: 175-194.

Tegegne, F. 2002. Fodder potential of Opuntia ficus-indica. Acta Hortic. 581: 343-346.

Tegegne, F., Kijora, C., Peters, K. J. 2007. Study on the optimal level of cactus pear (Opuntia ficus-indica) supplementation to sheep and its contribution as source of water. Small Rumin. Res. 72: 157-164.

Tesoriere, L., Fazzari, M., Allegra, M., Livrea, M. A. 2005. Biothiols, taurine, and lipid-soluble antioxidants in the edible pulp of Sicilian cactus pear (Opuntia ficus-indica) fruits and changes of bioactive juice components upon industrial processing. J. Agric. Food Chem. 53: 7851-7855.

Ventura-Aguilar, R. I., Bosquez-Molina, E., Bautista-Baños, S., Rivera-Cabrera, F. J. 2017. Cactus stem (Opuntia ficus-indica Mill): anatomy, physiology and chemical composition with emphasis on its biofunctional properties. J. Sci. Food Agric. 97: 5065-5073.

Wahome, P. K., Oseni, T. O., Masarirambi, M. T., Shongwe, V. D. 2011. Effects of different hydroponics systems and growing media on the vegetative growth, yield and cut flower quality of gypsophila (gypsophila paniculata L.). World J. Agric. Sci. 7: 692-698.

Wallace, R. S. 1995a. A family-wide phylogeny, subfamilial and tribal relationships, and suggestions for taxonomic realignments. IOS Bulletin 6: 13.

Wallace, R. S. 1995b. Molecular systematic study of the Cactaceae: Using chloroplast DNA variation to elucidate cactus phylogeny. Bradleya 13: 1-12.

Wallace, R. S., Gibson, A. C. 2002. Evolution and systematics. In "Cacti. Biology and Uses" (ed. by Nobel, P. S.), University of California Press, Berkeley, USA, p 1-22.

Wang, H. J., Wu, L. H., Wang, M. Y., Zhu, Y. H., Tao, Q. N., Zhang, F. S. 2007. Effects of amino acids replacing nitrate growth, nitrate accumulation, and macro element concentrations in Pak-choi (Brassica chinensis L.). Pedosphere 17: 595600 .

Yahia, E. M., Mondragón, J. C. 2011. Nutritional components and anti-oxidant capacity of ten cultivars and lines of cactus pear fruit (Opuntia spp.). Food Res. Int. 44: 2311-2318.

Yasseen, Y. M., Barringer, S. A., Splittstoesser, W. E. 1996. A note on the uses of Opuntia spp. in Central/North America. J. Arid Environ. 32: 347-353.

Zhao, M., Yang, N., Yang, B., Jiang, Y., Zhang, G. $2007 . \quad$ Structural characterization of water-soluble polysaccharides from Opuntia monacantha cladodes in relation to their anti-glycated activities. Food Chem. 105: 1480-1486. 